Arslan, S. \& Kavaklı, N. (2019). "I Know that I am No Good": An Analysis into the Translation Errors of Pre-service EFL Teachers. Bartın University Journal of Faculty of Education, 8(2), 688-706.

Bartın University Journal of Faculty of Education, 8(2), 688-706

Bartın Üniversitesi Eğitim Fakültesi Dergisi, 8(2), 688-706

buefad.bartin.edu.tr

\title{
"I Know that I am No Good": An Analysis into the Translation Errors of Pre-service EFL Teachers
}

\author{
Sezen Arslan*a, Nurdan Kavakl1 ${ }^{\mathrm{b}}$
}

\begin{tabular}{l} 
Article Info \\
\hline DOI: $10.14686 /$ buefad.517753 \\
\hline Article History: \\
Received: $\quad 06.01 .2019$ \\
Accepted: 22.04 .2019 \\
Published: $\quad 30.06 .2019$ \\
\hline Keywords: \\
Translation, \\
EFL teachers, \\
English language teaching \\
\hline Article Type: \\
Research Article
\end{tabular}

\begin{abstract}
Translation from source language (L1) to target language (L2) and/or vice versa plays an important role for language learners since they tend to use translation in order to understand and interpret the language utterances. Perspectives towards the use of translation in foreign language teaching and learning process have changed over the time. As the learners are not native speakers of L2, they are likely to utter some structurally or semantically deviant forms of language. For this reason, conducting an error analysis procedure might be of crucial importance in understanding which domains of language are erroneous for language learners in order to fix the problems and improve language proficiency. In Turkey, English Language Teaching bachelor degree programs include the translation course where student-teachers are supposed to handle translations from L1 to L2 and L2 to L1. In this study, the translation assignments of 30 pre-service EFL teachers were investigated through document analysis and findings point out that the errors fall into structural, lexical and translational/interpretational categories. Finally, the pedagogical implications were drawn in relation to the field.
\end{abstract}

\section{“Biliyorum İyi Değilim”: İngilizce Öğretmeni Adaylarının Çeviri Hatalarına Dair Bir İnceleme}

\begin{tabular}{|c|c|}
\hline \multicolumn{2}{|c|}{ Makale Bilgisi } \\
\hline \multicolumn{2}{|c|}{ DOI: 10.14686/buefad.517753 } \\
\hline $\begin{array}{l}\text { Makale } \\
\text { Geliş: } \\
\text { Kabul: } \\
\text { Yayın: }\end{array}$ & $\begin{array}{l}\text { mişi: } \\
06.01 .2019 \\
22.04 .2019 \\
30.06 .2019 \\
\end{array}$ \\
\hline \multicolumn{2}{|c|}{$\begin{array}{l}\text { Anahtar Kelimeler: } \\
\text { Çeviri, } \\
\text { İngilizce öğretmenleri, } \\
\text { İngilizce öğretimi }\end{array}$} \\
\hline \multicolumn{2}{|c|}{$\begin{array}{l}\text { Makale Türü: } \\
\text { Araştırma Makalesi }\end{array}$} \\
\hline
\end{tabular}

\section{$\ddot{\mathbf{O} z}$}

Kaynak dilden (L1) hedef dile (L2) ve/veya hedef dilden kaynak dile yapılan çeviriler, dil öğrenen kişiler için çok önemli bir rol oynamaktadır, çünkü dil öğrenenler, dili anlamak ve yorumlamak için çeviriyi kullanma eğilimindedirler. Çevirinin yabancı dil öğretiminde ve öğrenme sürecinde kullanılmasına yönelik bakış açısı da zamanla değişmiştir. Öğrencilerin yabancı dili kendi ana dilleri gibi konuşamama durumlarından dolayı, onların yapısal veya anlamsal olarak hatalı dil formları üretmeleri muhtemeldir. Bu nedenle, hata analizi yapmak, dil öğrencilerinin hangi alanlarda hata yaptığını bulmak, bu hataları düzeltmek ve öğrencilerin dil yeterliğini geliştirmek açısından son derece önemlidir. Türkiye'de İngiliz Dili Eğitimi lisans programlarında öğrencilerin kaynak dilden (Türkçe)-hedef dile (İngilizce) ve hedef dilden kaynak dile çeviri yaptığı çeviri dersi bulunmaktadır. Bu çalışmada, Türkiye'de bir devlet üniversitesinde okuyan 30 İngilizce öğretmeni adayının çeviri ödevleri doküman analizi aracılığıyla incelenmiş ve öğretmen adaylarının çeviri hatalarının yapısal, sözcüksel ve çevirisel/yorumsal kategorilerde olduğu ortaya çıkmıştır. Son olarak, alanla ilgili pedagojik çıkarımlarda bulunulmuştur.

\footnotetext{
*Corresponding Author: sezenarslan@gmail.com

a Assist. Prof. Dr., Van Yüzüncü Y1l University, Van/Turkey, https://orcid.org/0000-0002-5784-5704

bAssist. Prof. Dr., İzmir Demokrasi University, İzmir/Turkey, https://orcid.org/0000-0001-9572-9491
} 


\section{Introduction}

Essentially, translation takes up an integral part for a language learner since s/he continuously seeks the representations of words, phrases or clauses from the source language (L1) to target language (L2) or vice versa. Even though the experts suggest that translation is not a good way for improving language skills, it might be so demanding and challenging for learners to avoid translation. As the human mind is often in pursuit of establishing a connection and balance between the items learned, language learners, either consciously or subconsciously, try to find the equivalents of language items in both languages.

However, translation seems not to be cleared from the bad fame of Grammar-Translation Method for some years (Mogahed, 2011) as the prevalent wisdom claims that if language learning is based on translation merely, the learning does not yield effective results and that language should be taught by incorporating real-life language skills. In the 2000s, it appears that translation has been favored through documenting its payoffs (Artar, 2017; Çalış \& Dikilitaş, 2012, Samardali, 2017; Shoeib, 2016)

In Turkey, the bachelor degree program for English Language Teaching (ELT) includes translation as a compulsory course where L1 to L2 and L2 to L1 translations are incorporated (Council of Higher Education, 2018). The aim is to create a linguistic awareness into the similarities and differences between the two languages. For this reason, pre-service English as a foreign language (EFL) teachers are indulged in translation activities in which they are acquainted with translation techniques to be applied in different text genres. However, it is unlikely for student-teachers to produce error-free translations because of the structural and lexical disparity between languages. Therefore, conducting an error analysis in the translation texts will be considerably helpful in detecting what kind of errors are made and repeated. The frequency of incidences might guide the instructors in finding the sources of errors and misinterpretations, thereby providing an opportunity to fix them and improving language use.

In this study, translation assignments of 30 pre-service EFL teachers at a state university in Turkey were investigated through document analysis. The assignments were on different topics and collected regularly over 5 weeks during the spring semester in 2017. A meticulous analysis was performed in order to point out the errors in produced texts and the errors were classified into categories. This study is significant because it extends the findings to the literature and draws pedagogical conclusions related to the field of ELT.

\section{Translation and Language Teaching}

Collins Dictionary defines translation as a "piece of writing or speech that has been translated from a different language" (Translation, n.d). It acts as a tool that bridges L1 and L2 through conveying messages. Considering the semantic, linguistic and pragmatic structure of the language, the meaning could be communicated across the other language(s). Witte (2009) lists three kinds of translation as 1) intralingual translation, 2) interlingual translation, and 3) intersemiotic translation. Intralingual translation refers to the translation which is performed in one language and it includes paraphrases and re-interpretation within the same language. As for the interlingual translation, it concentrates on the translation performed from one language to another. The third type of translation, which is intersemiotic translation, includes the transformation of verbal language into symbols and images.

Differing approaches were developed towards the role of translation in foreign language teaching (FLT). In the early $20^{\text {th }}$ century, translation was dismissed since it was believed that the use of translation would ignore spoken production; furthermore, emphasizing communicative aspects of language in the 1960s and 1970s relied heavily on spoken language by rendering interaction as a prominent component in language teaching (Pavan, 2013). In the 1980s, translation started to emerge in language teaching (Kupske, 2015). Moreover, in the 2000s, with the appearance of Common European Framework of References for Languages: Learning, teaching, assessment (CEFR) which promotes diversity in languages and cultures, translation is seen as a mediation among the languages (Council of Europe, 2001). In other words, the framework perceives translation as an activity which promotes communication through accomplishing a settlement among the parties. Translation provides a medium that brings two or more languages together through realizing the negotiation. Widdowson (1978) states that the approach towards translation could either make create advantages or disadvantages. Accordingly, if the translation is performed in a way that is word for word, the use of mother tongue could prevent exchanging meanings in the foreign language. Therefore, he puts forward that translation should center around certain aspects of communication such as making descriptions, identifications and giving instructions. 
During the translation process, the learner goes through an active process cognitively in that s/he is supposed to understand the text in the L1 and reconstruct it in the L2 (Hervey, Loughridge, \& Higgings, 2006). Accordingly, the translation might not align with a passive engagement in the language learning process; contrarily, it may promote an active construction of the language through cognitive work since translating a text calls for comprehension, interpretation, and construction. Translation does not simply mean recreating the text instantly; contrarily, it encompasses reshaping the content by paying attention to some particular features within the target culture; for this reason, it could be used as a strategy for improving communicative competence through emphasizing semantics, specific contexts and functions (Al-Musawi, 2014). Leonardi (2011) thinks translation is a 'naturally-occurring' activity which cannot be avoided during foreign language learning since the learners always refer to their native language in order to make comparisons between the languages. He maintains that translation could be adopted as a fifth skill for improving foreign language proficiency.

When the historical background is considered, it could be understood that the translation was excluded from the foreign language classes until the late $20^{\text {th }}$ century since it was widely believed that relying on the translation would not promote communication and support authenticity, thereby hindering language development. For this reason, the use of translation has become a controversial topic for English language teaching by bringing along the assets and pitfalls. Adoption of translation has flourished in the recent decades because it has come to be seen as an efficient way to facilitate teaching through improving reading comprehension (Lee, 2013; Luitel, 2017; Pouya, 2012). Apart from that, Dagiliene (2012) suggests that translation could be employed for pedagogical purposes with the help of some activities such as making simplifications, paraphrases, corrections in translations and back translation. Thus, it could be integrated into the language classes in order to improve skills and enhance proficiency.

\section{Error Analysis}

Error analysis started to play a crucial role in applied linguistics in the 1970s (Richards, 1980) and it refers to the close systematic investigation into the learners' deviant utterances regarding the target language. Errors are considerably essential for foreign language learning and teaching process because they could denote some evidence for learning and sources of failure. Corder (1967) posits that errors are important for teachers, researchers, and learners. Accordingly, errors tell how well the learning aims are accomplished, which acts as a guide for teachers. As for researchers, they reveal which strategies and approaches are employed by the learners and highlight the ways the language is learned. Finally, they are crucial for the learners themselves since they are indispensable tools for testing hypothesis. Apart from Corder, Selinker (1972) also conducted in-depth studies and described the term 'interlanguage' which refers to a third place between one's L1 and L2. In other words, interlanguage denotes a different language system apart from either L1 and/or L2. According to him, L1 and L2 together with interlanguage constitute three language systems.

Errors are integral parts of language learning and teaching since they provide an insight into the learners' language development. When the learners attempt to produce utterances in the L2, errors might be inevitable; however, noticing these 'ill-formed' structures and seeking the source of them might be of crucial importance for teachers and researchers, as well. Language learning is extremely fragile to cross-linguistic interference; for this reason, it is quite complicated by nature. Therefore, errors are intertwined into the pedagogic process; they are to be acknowledged, monitored, and documented meticulously. Subsequently, meaningful feedback could be provided by creating an incentive for better learning.

\section{Error Analysis in Translation}

Translation contains two types of knowledge: 1) the knowledge of interpreting the design and the meaning in the provided source language, and 2) the knowledge of reproducing the design and the meaning in the provided target language (Vivanco, Palazuelos, Hörmann, Garbarini, \& Blatrach, 1990). That is to say, the translator is firstly expected to comprehend the content crammed into the L1 and, later, re-structure the form in accordance with the L2. In order to come up with a well-produced translation, cognitive process of comprehension is to be carried out effectively in order to grasp the content to be translated. Eventually, representation might be performed by taking into the contextual tenets within the language. As the translation entails cognitive capabilities apart from having a good command of restraints regarding L1 and L2, it might be deemed as a work that requires too much effort. As a result, translation errors could happen because they may be inevitable and unavoidable even though a 
thorough work is done. In this context, translation errors refer to the deviant oral and written forms which do not conform to the linguistic, pragmatic, semantic and cultural framework of the target language. Nord (1997) classified translation errors into four categories:

1. Pragmatic translation errors: They refer to the errors occurring as a result of the inability to convey meanings in a social context. According to Nord, the results of these errors could be severe since the message between the receiver and sender is not communicated in the right way so that misunderstandings are likely to happen. He posits that a thorough comparison should be done in order to identify a pragmatic translation error.

2. Cultural translation errors: They are related to the inadequacy in adapting or restructuring the conventions pertaining to the given culture.

3. Linguistic translation errors: They result from impaired utterances in relation to linguistic structures.

4. Text-specific translation errors: They are mainly investigated by paying attention to functional and pragmatic aspects and they indicate textual problems. Basically, all of the errors aforementioned above could cause text-specific translation errors.

Likewise, Pym (1992) asserts that there are two types of errors: binary errors and non-binary errors. He says: "For binarism, there is only right and wrong; for non-binarism there are at least two right answers and then the wrong ones" (p.281). Non-binary errors could be correct but not be proper in terms of context; therefore, they can be used to teach 'translational knowledge'. To add, Vivanco et al. (1990) claim that errors could be due to either translation errors or translator's being lack in target language competence and that it is far harder to find the main source; thus, source and target texts should be accessible in need.

Singling out the errors or producing translations with low-error rates is essential for getting the message across properly and producing true interpretations. Erroneous translations could lead misunderstandings and serious consequences in communication. Melis and Albir (2001) think that the importance of errors should be handled in relation to:

1. The text as a whole (whether it affects a key idea or a subordinate idea)

2. The coherence and cohesion of the target text

3. The degree of deviation from the sense of the original text, particularly if this deviation is likely to remain undetected by the reader of the translation

4. The functionality on a communicative level of the target text (infringement of text type conventions, etc.)

5. Adverse consequences regarding the purpose of the translation (resulting in the failure to sign a contract, sell a product, etc.) (p.282).

As seen, perspectives towards translational errors stand on the context regarding the text itself and the results of misinterpretation by indicating that problems are to be treated by paying attention to the sources and consequences.

\section{Method}

\section{Purpose of the Study}

The main aim of the study is to make an investigation into the types of translation errors made by the preservice EFL teachers. Thus, all of the errors are listed under certain categories and each category is provided with the frequencies peculiar to the recurring errors.

\section{Research Design}

Document analysis which is a qualitative research method was employed in this study. Bowen (2009) states that the revision and evaluation of the documents are conveyed during document analysis. According to him, documents are used since they introduce contextual information and provide further information through enabling questioning, verification, additional data, and an instrument for keeping track of improvement or change. In this case, the document analysis method was used to allow a detailed probe into the identification and classification of the translation errors in detail.

\section{Setting and Participants}


30 pre-service EFL teachers who studied at a state university in Turkey were recruited for this study. This sample received Turkish to English Translation Course during the spring semester in 2017. During this semester, the participants were given Turkish texts on language, translation, movies, star signs, and sports and they were asked to translate them into English. The major objective to use a variety in terms of text content is to provide them with different contexts and conventions each time.

\section{Data Collection and Analysis}

Each week, an assignment was given to pre-service EFL teachers on one topic and the student-teachers were supposed to complete the translation in one week. At the end of the 5 weeks, all of the translation assignments were collected. The analysis was initiated with the identification of the errors through document analysis method. Subsequently, the errors were classified into categories in order to define the translation error types. Inter-rater reliability was adopted so that all of the texts could be investigated by the two researchers and one field expert so as to ensure reliability. The classification of the errors was performed until reaching a common ground with the researchers and the field expert.

\section{Findings}

All of the translation texts were analyzed meticulously and the findings point out that the translation errors made by the pre-service EFL teachers fall into three main categories: 1) Structural, 2) Lexical, and 3) Translational/Interpretational.

The first category refers to the errors regarding grammatical construction of the sentences and mechanics including misspelled words, punctuation and capitalization. The second category is related to the lexical errors addressing improper word choice. Finally, the last category harkens back to the errors resulting from the rendering or interpreting the text content. To put it another way, it shows the inability to convey the meaning of the source text through omission and/or addition of some words and phrases.

The main categories with accompanying sub-categories of frequently recurrent errors are illustrated in the table below:

Table 1. Translation Errors

\begin{tabular}{ccc}
\hline Categories & Sub-categories & Frequency \\
\hline Structural & Grammar & 155 \\
& Mechanics & 45 \\
Lexical & Improper word choice & 69 \\
Translational/Interpretational & Incompetence in conveying the & 37 \\
& source text meaning & 37 \\
\hline
\end{tabular}

As seen in the table above, the most frequent errors are found to be related to the structural composition of the sentences. In a word, it seems that some of the structural items were not put together in the correct way through cultivating mechanics.

\section{Structural Errors}

The recurrent language errors within the structural category are summarized in the following table: 
Table 2. Structural Errors in Translations

\begin{tabular}{|c|c|c|}
\hline Sub-category & Components & Frequency \\
\hline \multirow{14}{*}{ Grammar } & Subject-verb agreement & 25 \\
\hline & Relative clauses/pronouns & 24 \\
\hline & Sentence fragments & 17 \\
\hline & Prepositions & 16 \\
\hline & Plural/Singular nouns & 14 \\
\hline & Adverbs & 11 \\
\hline & Passive/Active voice & 10 \\
\hline & Definite articles & 8 \\
\hline & Indefinite articles & 7 \\
\hline & Conjunctions & 6 \\
\hline & Pronoun references & 5 \\
\hline & Verb forms & 5 \\
\hline & To-infinitives & 4 \\
\hline & Comparatives & 3 \\
\hline \multirow{6}{*}{ Mechanics } & Spelling & 19 \\
\hline & Comma & 18 \\
\hline & Semi-colon & 2 \\
\hline & Quotation marks & 2 \\
\hline & Capitalization & 2 \\
\hline & Writing Numbers & 2 \\
\hline
\end{tabular}

It illustrates that the most recurring component was subject-verb agreement $(N=25)$. Some of the participants came up with deviant utterances in binding the subjects and verbs of the sentences without considering the plurality or singularity. Some sample excerpts from the participants' target texts denoting the subject-verb disagreements are illustrated below:

"There are some communicational features that determine_every text according to position..."

"...some problems about issues that is related with your group of friends..."

"Running which is done at tracks that is appropriate to..."

As displayed above, the subjects and the verbs in the subordinate clauses do not agree with each other in terms of plurality/singularity.

This is followed by the erroneous structures $(N=24)$ with regard to relative clauses/pronouns that are either missing or improperly used. The sample utterances herein are given in order to illustrate the improperly built relative clauses:

"The movie which Watson plays..."

"There are situations that one word or clause gets a whole..."

"The movie that Jake meets with audience..." 
To add, the category of sentence fragments $(N=17)$ is the third frequently seen component which describes incomplete sentences as they do not have the main components such as verb or subjects. Therefore, they do not sustain themselves in conveying meaning.

"In every text, due to the social setting in which it is formed, there are a couple of communicative features that specify." (the object is missing) incomplete)

"It does not mean that underestimation of importance of clauses or words." (the subordinate clause is

"Beauty and the Beast compiled by the French writer in the $18^{\text {th }}$ century and giving inspiration to several works." (the verb is missing)

In order to produce a correct sentence, subjects, verbs and objects are to be incorporated in the correct way. In the sentences above, it seems that the main components (object and verbs) are missing, indicating incomplete sentences.

Within the sub-category of mechanics, spelling errors $(N=19)$ are the most repeated ones that are comprised of scrambled or omitted letters. Some examples are extracted as follows:

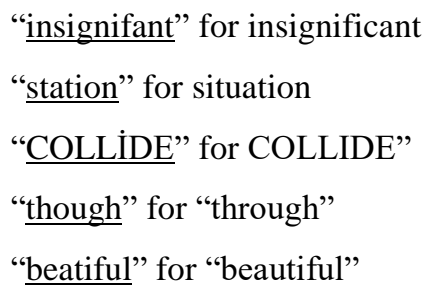

Secondly, comma use $(N=18)$ appears to be problematic for some participants since it is added into some cases where it is not necessary. In some texts, the comma is found to be misused by being added right after the subject.

"Thus, circumstances where a single word or sentence gain a whole text function _do not exist."

"Besides that, a successful translation, can occur with the close acknowledgement of some communicational features..."

In the Turkish language, the comma is generally placed after the subject in long sentences in order to highlight the subject in order to prevent any confusion (Turkish National Association, n.d). It appears that some participants transferred this punctuation rule of their native language into the target language. The other punctuation errors refer to semi-colon $(N=2)$ and quotation marks $(N=2)$ since few texts include misused and missed items. Finally, as displayed in the table, errors due to the capitalization $(N=2)$ and numbering $(N=2)$ were barely observed.

\section{Lexical Errors}

Turning back to Table 1 , one could easily see that improper word choice $(N=69)$ was the second most common errors for the participants. As seen, some expressions were wordy and imprecise, blocking the conducted original meaning. Some examples of representation were given below:

"It does not mean that it reduces the importance of words and sentences." (wordy expression)

"...some conversational features that detects the text due to the communicational state in which it takes shape.” (imprecise meaning)

“... a proper translation can take shape through close recognition of some communicational properties..." (wrong word choice)

\section{Translational/Interpretational Errors}

Apart from structural and lexical errors, within the main category of translational/interpretational errors, incompetence in conveying the source text meaning $(N=37)$ which is meant to weed out the information, idea or any word within the text was observed. Some participants were found to abstain from translating the words or phrases which may be challenging to them; however, this act of omission failed to bring out the correct translational 
meaning and thus changed the tune. Furthermore, some others added some words or ideas that the original text did not include, which could be seen in the following excerpts.

"...considering so many relations of the text beyond the visible objective boundaries is the main condition of a good translation." (The original text does not state it as a main condition but a pre-condition, producing a translational/interpretational error).

"In fact, a single word or sentence can be functioned as a whole text." (But, the original text says that "there are some cases where a single word or sentence can be functioned as a whole text).

“...it is extremely important to know both source and target language..." (Even though the original text does not indicate any level of importance, the student-teacher prefers to mention an expression of importance).

\section{Discussion and Conclusion}

The findings point out that the translational errors fall into three main categories as 1) structural, 2) lexical, and 3) translational/interpretational errors. Structural errors appear as the most predominantly observed components including grammar and mechanics. That is to say, it could be concluded that the vast majority of the texts are disorganized in terms of structural patterns of the target language. According to the robust analysis conducted for this study, it is apparent that some participants had challenges in building subject-verb agreement, using relative clauses/pronouns, and forming well-established sentences considering the syntax. Taking these three forms of structural errors into consideration, one could claim that the participants experienced difficulties with longer sentences. Short and direct sentences do not necessarily include relative clauses or pronouns as there may be no need to combine any subordinate or additional sentence. The distance between the subject and verb is generally short, so they do not fall apart from each other. Contrarily, in the longer sentences, since there could be some dependent clauses which need to be connected to other clauses, there may be the possibility of producing poorlyformed utterances regarding relative clauses or subject-verb agreement.

As for mechanics, misspelled words due to the omitted or scrambled letters constitute the big portion. To put it simply, some of the participants do not sound prepared for immaculate production of words. These findings echo the study of Al-zuoud and Kabilan (2013) in which they investigated the EFL learners' spelling errors and found out that the majority of the errors was 'substitution' and 'omission' errors. Likewise, Seitova's study (2016) that made a probe into the language errors of Russian Kazakh learners of English pointed out that one of the major sources of errors was related to spelling in the translations and compositions. Herein, in the context of this study, it could be stated that the participants are likely to have relinquished spelling check. With this in mind, this mechanical failure could be handled in conjunction with the lapse in lexical representation.

Apart from spelling errors, punctuation, particularly, comma use seems to be problematic for some participants. It is observed that comma was frequently misused in longer sentences and that some attempted to place it after the subject in order to distinguish it from other sentence components. This confusion would be understandable to a degree since the comma is prescribed in signifying and emphasizing subjects in the Turkish language. Therefore, a negative interlanguage interference can be claimed to exist at this point as the participants were unable to distance themselves from their native language.

The second most common errors lie within the lexical category which indicates improper word choice. Some of the participants seemed to have difficulty in choosing the correct word and produced wordy utterances. These findings corroborate with the findings of some previous studies (Parvizi, Shafipour \& Mashayekh, 2016; Pojprasat, 2007) which indicate that the wrong word choice is one of the prevalent translational errors. It is noteworthy to state that word choice might be an indicator of low lexical competence indeed. Cronbach (1942, as cited in Stahl \& Bravo, 2010) posits that one should know the definition of the word with multiple meanings, define a word, choose the appropriate use, apply it to all contexts, and use it actively. As seen, knowing the definition of the word is not adequate; to know a word entails many aspects such as varying meanings and usages. From this point of view, looking up words in a dictionary, choosing one of them which is pleasant to the ear and using it arbitrarily in any context is not an effective way for building vocabulary. The primary concern is how to choose and use the right word through forcing out the wordy and imprecise utterances.

Coupled with improper word choice, it would be expected for the participants to produce texts which include vague representation of the source text into the target text. Being incapable of finding the suitable word to the 
context, some participants seemed to omit some words/phrases or add ideas that the original text do not have. Dimitriu (2004) postulates that omission could be thought as a strategy employed by expert translators in order to adapt the text culturally, linguistically or ideologically for the readers by omitting some words or phrases from the source text. Herein, within the context of this study, as there is no need to make adjustments in accordance with the target society, the act of omission committed by some participants is not considered as a translation strategy. Contrarily, deletion or addition of some other ideas through improper words and phrases appears to be a sink or swim approach taken by some participants since delivering a paper with some parts deleted is believed not to give a good impression.

\section{Pedagogical Implications}

Analyzing the frequency of common errors, one could conclude that they are not the products of a simple distraction. A problem seems to be engraved in some uses of language such as certain grammatical structures and lexis. In order not to deteriorate the situation, it could be recommended that EFL pre-service teachers could be encouraged to keep a writing journal. They could jot down about any issue, topic or event they like and revise their notes on their own or with peers, periodically. This would prevent them to fall a prey into the structural or lexical challenges as the regular writing could make it easier for them to recall the words and certain structures with minimal effort. However, writing is ignored as it is deemed as demanding and it does not yield immediate outcomes with certain payoffs. For this reason, the instructors could center on writing through assignments related to the offered courses and monitor the students' writing in terms of form and content. To put it briefly, the point should not only to deliver a written product on any topic but to craft a well-established one since the aim is to lead knowledgeable and proficient language teachers.

Furthermore, encouraging student-teachers to use a Thesaurus could be a minor but effective way to improve translations in that it offers words with similar and opposite meanings. Some of the online Thesaurus websites order the words in relation to synonymity and antonymity and in terms of semantic relevance. Instead of idling in uncertainty, utilization of a Thesaurus could help student-teachers to find the correct word by paying attention to words' conceptual relations. Apart from Thesaurus, monolingual dictionaries which explain the definitions of L2 words in L2 with some examples could be used. Bilingual dictionaries could be misleading for some learners as they may provide direct L1 equivalents; however, the offered definition would not be perfectly fit into the L2 context. Therefore, monolingual dictionaries are relatively effective since they introduce the context in which the words are used. 


\section{“Biliyorum İyi Değilim”: İngilizce Öğretmeni Adaylarının Çeviri Hatalarına Dair Bir İnceleme}

Giriş

Dil öğrenen kişi kelime ve cümlelerin kaynak dilden ana dile ya da ana dilden kaynak dile karşılıklarını sürekli olarak aradığından dolayı çeviri, dil öğrenen kişi için son derece önemlidir. Uzmanlar, çevirinin dil becerilerini geliştirmek için etkili bir yol olmadığını söylese de, dil öğrenenler açısından çeviriden kaçınmak oldukça zor olabilir. İnsan beyni, öğrenilen ögeler arasında bilerek ya da bilinç altında sürekli bir bağlantı ve denge kurmaya çalıştığ 1 için, dil öğrenenler her iki dildeki dil ögelerinin karşılığını bulmaya çalışırlar.

Ancak, çeviri Dilbilgisi-Çeviri Yöntemi'nin kötü namından bir türlü kurtulamamış görünmektedir (Mogahed, 2011) çünkü yaygın görüş, dil öğretiminin çeviriye odaklı yürütülmesi halinde etkili sonuçlar alınamayacağı, dolayısıyla dil öğretiminin gerçek yaşam becerilerini içermesi yönündedir. 2000'li yıllarda, dil öğretimine çevirinin dahil edilmesinin olumlu sonuçları ortaya konmuş ve bu yüzden çevirinin desteklendiği görülmektedir (Artar, 2017; Çalış \& Dikilitaş, 2012, Samardali, 2017; Shoeib, 2016)

Türkiye'de, İngiliz Dili Eğitimi lisans programlarında, kaynak dilden hedef dile ve hedef dilden kaynak dile çevirinin yapıldığı çeviri dersi zorunlu kılınmıştır (Yükseköğretim Kurulu [YÖK], 2018). Amaç, iki dil arasındaki benzerlik ve farklılıklarla ilgili dilsel bir farkındalık yaratmaktır. Bu nedenle, İngilizce öğretmeni adayları farklı metin türlerinde uygulanacak çeviri teknikleri hakkında bilgi sahibi olacağı çeviri etkinliklerine dahil olmaktadırlar. Fakat, öğretmen adaylarının diller arasındaki yapısal ve sözcüksel farklılıklardan dolayı hatasız çeviri üretmeleri pek mümkün değildir. Bu nedenle, çeviri metinlerinde bir hata analizi yapmak, ne tür hataların yapıldığını ve tekrarlandığını tespit etme hususunda oldukça yardımcı olacaktır. Hataların sıklığı, eğitmenlere hata kaynaklarını ve yanlış yorumlamaları bulma konusunda rehberlik edebilir; bu sayede, hata analizi yürütmek, hataların düzeltilmesi ve dil gelişiminin sağlanması için bir firsat sunabilir.

Bu çalışmada, Türkiye'de bir devlet üniversitesinde 30 İngilizce öğretmeni adayının çeviri ödevleri, doküman analizi yöntemiyle incelenmiştir. Farklı konularda olan çeviri ödevleri, 2017 bahar dönemi'nde 5 hafta boyunca eğitmenler tarafından düzenli olarak toplanmıştır. Öğretmen adaylarının çeviri metinlerindeki hataları belirlemek için titiz bir inceleme yapılmış ve hatalar kategorilere ayrılmıştır. Bu çalışma, ortaya çıkan bulguları var olan literatüre katması ve İngilizce öğretimi alanıyla ilgili pedagojik çıkarımlarda bulunması açısından önem arz etmektedir.

\section{Çeviri ve Dil Öğretimi}

Collins sözlüğü, çeviriyi "farklı bir dilden çevrilmiş bir yazı ya da konuşma" olarak tanımlamaktadır (Translation, b.t). Çeviri, kaynak ve hedef dil arasındaki iletiler arasında bağlantı kuran bir köprü işlevi görmektedir. Dilin semantik, dilsel ve pragmatik yapısını göz önünde bulundurarak, diğer diller arasında iletişim sağlanmış olur. Witte (2009), 1) intra (Dil içi) çeviri, interlingual (diller arası) ve 3) intersemiotic (göstergeler arası) çeviri olarak üç tür çeviriden bahsetmektedir. Dil içi çeviri, bir dil içinde yapılan çeviriyi ifade eder ve aynı dil içinde yapılan yorumlamaları içerir. Diller arası çeviri, bir dilden diğerine yapılan çeviridir. Göstergeler arası çeviri ise, dilsel çevirinin sembollere ve görüntülere dönüşümü anlamına gelmektedir.

Çevirinin yabancı dil öğretimindeki rolüne yönelik farklı yaklaşımlar geliştirilmiştir: 20. yüzyılın başlarında, çeviri kullanımının konuşma becerisini ihmal ettiğine dair olan inanıştan dolayı, çeviri İngilizce öğretimine dahil edilmemiştir. Ayrıca, 1960 ve 1970'li yıllarda, dilin iletişimsel yönünün vurgulanmasından ötürü, o yıllarda konuşma becerisine yoğunlaşılmış ve iletişim dil öğretiminin önemli bir ögesi haline gelmiştir (Pavan, 2013). 1980'lerde, çeviri, yeniden dil öğretimine dahil edilmeye başlanmıştır (Kupske, 2015). Ayrıca, dilsel ve kültürel çeşitliliği destekleyen Avrupa Dilleri Ortak Çerçeve Metni'nin ortaya çıkışıyla, çeviri diller arasında arabulucu işlevi gören bir etmen olarak görülmüştür. (Avrupa Konseyi, 2001). Başka bir deyişle, bu metin çeviriyi taraflar arasında anlaşma sağlayan bir etkinlik olarak görmektedir. Çeviri, iki ya da daha fazla dil arasında uzlaşmayı gerçekleştiren bir aracıdır. Widdowson (1978), çeviri yaklaşımlarının, dil öğrenimi açısından dezavantaj ya da avantaj yarabileceğini ifade etmektedir. Ona göre, çeviri, kelimesi kelimesine yapılıyorsa, ana dilin kullanımı yabancı dildeki anlam alışverişini engelleyebilir. Bu yüzden, çevirinin, tanımlamalarda bulunma, açıklama yapma ve yönerge verme gibi iletişimin bazı yönlerini vurgulamasını gerektiğini öne sürmektedir.

Çeviri boyunca, dil öğrencisi bilişsel olarak etkin bir süreçten geçer çünkü kaynak dildeki metni anlaması ve onu hedef dilde tekrar yapılandırması gerekmektedir (Hervey, Loughridge \& Higgings, 2006). Buna göre, çeviri, 
dil öğrenme sürecine pasif bir şekilde dahil edilmeyebilir; aksine, bir metnin çevrilmesi, anlama, yorumlama ve yapılandırma işlemlerini gerektirdiğinden dilin aktif bir şekilde kullanımını sağlayabilir. Çeviri, basit anlamda metni sadece yeniden yaratmak anlamına gelmemektedir, bilakis, hedef kültür içindeki bazı özelliklere dikkat ederek, içeriğin yeniden şekillendirilmesini de ifade eder. Bu nedenle, dilin semantik yapısı, belirli bağlamları ve işlevleri de vurgulanarak iletişimsel yetkinliğin geliştirilmesi için bir strateji olarak kullanılabilir (Al Musawi, 2014). Leonardi (2011), çevirinin yabancı dil öğrenimi sırasında kaçınılması mümkün olmayan “doğal olarak gerçekleşen” bir etkinlik olduğunu düşünmektedir; çünkü, öğrenciler diller arasında karşılaştırma yapmak için her zaman kendi dillerine başvurmaktadır. Leonardi, yabancı dil yeterliğini artırmak için çevirinin beşinci bir beceri olarak benimsenebileceğini savunmaktadır.

Tarihsel arka plan göz önüne alındığında, çevirinin yabancı dil sınıflarına 20. yüzyıl sonlarına kadar dahil edilmediği anlaşılmaktadır; çünkü, çevirinin iletişimi ve gerçekliği desteklemediğine ve dolayısıyla da dil gelişimini engellediğine inanılmaktaydı. Son yıllarda, çeviri, okuduğunu anlama becerisini geliştirmenin etkin bir rolü olarak görüldüğü için tekrar gündeme gelmiştir (Lee, 2013; Luitel, 2017; Pouya, 2012). Bunun yanı sıra, Dagiliene'ye (2012) göre, çeviri basitleştirilmiş metinler üretme, metinleri tekrar yorumlama, çevirilerde düzeltmelerde bulunma ve geri çeviri yapma gibi etkinlikler aracılığıyla pedagojik amaçlar için kullanılabilir. Bu yüzden, çeviri, dil becerilerini ve dil yetkinliğini artırma amacıyla dil sınıflarına entegre edilebilir.

\section{Hata Analizi}

Hata analizi, 1970’lerde uygulamalı dilbilimde önemli bir rol oynamaya başlamıştır (Richards, 1980) ve öğrencilerin hedef dile ilişkin hatalı ifadeleri üzerine yapılan sistematik çalışmaları ifade etmektedir. Hatalar, yabancı dil öğrenme ve öğretme süreci için oldukça önemlidir; çünkü, öğrenme durumunu ve başarısızlığın sebeplerini açıklayabilir. Corder (1967), hataların öğretmenler, araştırmacılar ve öğrenciler için önemli olduğunu belirtir. Ona göre, hatalar öğretmenler için bir rehber görevi görmekte ve öğrenme hedeflerinin ne denli başarıldığını göstermektedir. Araştırmacılar içinse, hatalar öğrenciler tarafından hangi tekniklerin ve yaklaşımların kullanıldığını belirtmesi ve dil öğrenme yollarını aydınlatması bakımından önemlidir. Son olarak, hatalar öğrenciler için de mühimdir çünkü hipotezleri test etme bakımından vazgeçilmez araçlardır. Corder'ın yanı sıra, Selinker de (1972), konuyla ilgili olarak ayrıntılı çalışmalar yürütmüş ve kaynak dil ile hedef dil arasında üçüncü bir dil olan "interlanguage" terimini (ara dil) tanımlamıştır. Başka bir deyişle, ara dil, kaynak dil ve/veya hedef dilden ayrı bir dil olan farklı bir dil sistemi anlamına gelmektedir. Ona göre, kaynak ve hedef diller, ara dil ile birlikte üç farklı dil sistemidir.

Hatalar, dil öğrenimi ve öğretiminin ayrılmaz parçalarıdır; çünkü, öğrencilerin dil gelişimine dair ışık tutarlar. Öğrenciler, hedef dilde bir şeyler üretmeye çalıştıklarında, hatalar kaçınılmazdır; fakat bu 'yanlış şekillendirilmiş' yapıları fark etmek ve onların kaynaklarını aramak, son derece önemlidir. Dil öğrenimi, diller arası etkileşime karşı son derece hassastır; bu yüzden, doğası gereği son derece karmaşıktır. Bundan ötürü, hatalar, eğitimbilim ile iç içedir; hatalar onaylanmalı, izlenmeli ve titiz bir şekilde belgelenmelidir. Daha sonra, daha iyi bir öğrenme için anlamlı bir geri bildirim sağlanabilir.

\section{Çeviride Hata Analizi}

Çeviri iki tür bilgi içerir: 1) kaynak dildeki anlam ve tasarımı yorumlama bilgisi ve 2) hedef dildeki tasarımı ve anlamı yeniden üretme bilgisi (Vivanco, Palazuelos, Hörmann, Garbarini, \& Blatrach, 1990). Yani, çevirmen önce kaynak dildeki içeriği anlar ve daha sonra, hedef dile uygun olarak onu yeniden yapılandırır. İyi bir çeviri için, etkin yönetilen bir bilişsel kavrama sürecine ihtiyaç vardır. Dil içerisindeki bağlamsal ilkeler dikkate alınarak çeviri gerçekleştirilebilir. Çeviri, kaynak ve hedef dile ait sınırlılıkların bilinmesinin yanı sıra, bilişsel yeterliklere de sahip olunmasını gerektirdiğinden, çok fazla çaba gerektiren bir iş olarak düşünülebilir. Sonuç olarak, her ne kadar kapsamlı bir çalışma yapılsa da çeviri hataları olabilir; çünkü, hatalar kaçınılmazdır. Bu bağlamda, çeviri hataları hedef dilin dilsel, pragmatik, semantik ve kültürel çerçevesine uymayan sözlü ve yazılı biçimlerini ifade eder. Nord'a (1997) göre, çeviri hataları 4 gruba ayrılır:

1. Pragmatik çeviri hataları: Bu hatalar, sosyal bağlamdaki anlamları ifade edememekten kaynaklanır. Nord'a göre, bu hataların sonuçları ciddi olabilir; çünkü, alıcı ve gönderici arasındaki mesajlar, doğru bir şekilde iletilmemiştir ve böylece yanlış anlaşılmaların olması muhtemeldir. Pragmatik bir çeviri hatasının bulunması için, ayrıntılı bir karşılaştırmanın yapılmasını öne sürmektedir. 
2. Kültürel çeviri hataları: Bir kültürdeki standartların uyarlanması ve yeniden şekillendirilmesindeki yetersizlikle ile ilintilidir.

3. Dilsel çeviri hataları: Dilsel yapılardaki hatalardan dolayı oluşmaktadırlar.

4. Metne özgü hatalar: Temel olarak, metinlerin işlevsel ve pragmatik yönleriyle ilgilidir ve metinle ilgili sorunları ifade etmektedir. Aslında, yukarıda adı geçen tüm hata çeşitleri, metne özgü hatalardır.

Benzer bir şekilde, Pym (1992), iki tür hata olduğunu iddia etmektedir. Çift ve çift olmayan hatalar. Pym, şu şekilde belirtir: "Çift olma durumunda, sadece doğru ve yanlış cevaplar vardır; çift olmayan durumlarda ise, en az iki doğru cevap ve yanlış cevaplar vardır.” (s. 281). Çift olmayan hatalar, doğru olabilir ama bağlam açısından uygun olmayabilir; bu yüzden, 'çevirisel bilgiyi' öğretmek için kullanılabilir. Bunun yanı sıra, Vivanco ve diğerleri (1990) ise, hataların ya çeviriden ya da çeviren kişinin hedef dile yeteri kadar vakıf olmadığından kaynaklandığını ve hatanın ana kaynağının bulunmasının zorluğundan ötürü, hedef ve kaynak dilde yazılan metinlerin ulaşılabilir olması gerektiğini iddia eder.

Hatasız bir çeviri ve metnin mesajını karşı tarafa net bir şekilde ulaştırmak için, çevirileri hatalardan arındırmak ya da az bir hata oranı ile düzenleyebilmek son derece önemlidir. Hatalı çeviriler yanlış anlaşılmalara ve ciddi sonuçlara sebebiyet verebilir. Melis ve Albir (2001), hataların önemini aşağıda belirtilen etmenlerle ilişkilendirmiştir:

1. Bir bütün olarak metin (Metindeki asıl fikrin ya da yan fikrin etkilenip etkilenmemesi)

2.Hedef dilde yazılmış metnin uyumu

3. Orijinal metinden sapma miktarı; özellikle de çeviriyi okuyan kişi tarafindan fark edilmesi küçük bir ihtimal olan sapmalar

4. Hedef dilde yazılan metnin iletişimsel seviyedeki işlevselliği (metin halindeki bir anlaşmanın ihlali gibi)

5. Çevirinin amacına ters düşen sonuçlar (sözleşmenin imzalanamaması, ürünün satılamaması gibi sonuçlara sebebiyet vermek) (s. 282)

Görüldüğü üzere, çeviriyle ilgili hatalara yönelik görüşler, metnin kendisi ve metnin yanlış yorumlanmasıyla ilgilidir ki bu da, hatalardan kaynaklanan problemlerin hata kaynaklarına ve hataların sonuçlarına dikkat ederek çözümlenmesi gerektiğini göstermektedir.

\section{Yöntem}

\section{Çalışmanın Amacı}

Çalışma, İngilizce öğretmeni adayları tarafından yapılan çeviri hatalarının türlerini araştırmaktadır. Bu sebeple, yapılan tüm hatalar belirli kategoriler altında listelenmiş ve her bir kategoride, tekrarlanan hatanın frekansı verilmiştir.

\section{Araştırma Deseni}

$\mathrm{Bu}$ çalışmada, nitel bir analiz yöntemi olan doküman analizi kullanılmıştır. Bowen (2009), doküman analizinde, belgelerin gözden geçirilip değerlendirildiğini belirtir. Ona göre, belgeler bağlamsal bilgiyi içerdiği için ve sorgulama, doğrulama, ek bilgi ve herhangi bir değişimi gösterdiğinden ya da gelişimi izleyecek bir araç olarak kullanılabilmeye olanak tanıdığından dolayı kullanılabilir. Bu çalışmada, doküman analizi yöntemi, çeviri hatalarının detaylı bir şekilde tanımlanması ve sınıflandırılması amacıyla kullanılmıştır.

\section{Çalışma Grubu}

Bu çalışmaya, Türkiye'de bir devlet üniversitesinde öğrenim gören 30 İngilizce öğretmeni adayı katılmıştır. Katılımcılar, 2017 bahar döneminde, Türkçe-İngilizce Çeviri Dersi almıştır. Dönem boyunca, katılımcılara dil, çeviri, filmler, burçlar ve sporla ilgili Türkçe metinler verilmiş ve katılımcılardan bu metinleri İngilizce 'ye 
çevirmeleri istenmiştir. Metin içeriği açısından çeşitliliğin kullanılmasındaki amaç, katılımcılara her seferinde farklı bağlamlar ve kullanımları göstermektir.

\section{Verilerin Analizi}

İngilizce öğretmeni adaylarına her hafta bir konuda ödev verilmiştir ve onların bu ödevleri bir hafta içerisinde tamamlanması istenmiştir. 5 haftanın sonunda, tüm çeviri ödevleri toplanmıştır. Verilerin analizi, hataların doküman analizi yöntemi ile tanımlanması şeklinde başlamıştır. Daha sonra, çeviri hata türlerini tanımlamak için, hatalar kategorilere ayrılmıştır. Bu çalışmada puanlayıcılar arası güvenirlik benimsenmiş; bu yüzden güvenirliği sağlamak için tüm metinler iki araştırmacı ve bir alan uzmanı tarafından incelenmiştir. Araştırmacılar ve alan uzmanı arasında uzlaşma sağlanarak hataların sınıflandırılması yapılmıştır.

\section{Bulgular}

Tüm çeviri metinleri titiz bir şekilde incelenmiş ve bulgulara göre İngilizce öğretmeni adayları tarafindan yapılan çeviri hataları 3 kategoriye ayrılmıştır: 1) Yapısal, 2) Sözcüksel, ve 3) Çevirisel/Yorumsal.

İlk kategori, cümlelerin dilbilgisi yapıları ve yanlış yazılmış kelimeler, noktalama, büyük harf kullanma gibi biçimle ilgili hataları ifade etmektedir. İkinci kategori, yanlış kelime seçimine yönelik sözcüksel hatalarla ilgilidir. Son olarak, son kategori metin içeriğinin oluşturulmasından ya da yorumlanmasından kaynaklı hatalarla ilintilidir. Başka bir deyişle, bu kategori, bazı sözcük ve ifadelerin atılması ve/veya eklenmesinden dolayı kaynak dilde yazılmış metindeki anlamı ifade edememe durumuyla ilgilidir.

Sıkça yapılan hatalarla ile ilgili ana kategoriler ve ilgili alt kategoriler aşağıdaki tabloda gösterilmektedir:

Tablo 1. Çeviri Hataları

\begin{tabular}{ccc}
\hline Kategoriler & Alt kategoriler & Frekans \\
\hline Yapısal & Dilbilgisi & 155 \\
& Biçim & 45 \\
Sözcüksel & Uygun olmayan kelime kullanımı & 69 \\
Çevirisel/Yorumsal & Kaynak metindeki anlamı ifade \\
& edememe & 37 \\
\hline
\end{tabular}

Yukarıdaki tabloda görüldüğ̈̈ gibi, en sık yapılan hataların cümlelerin yapısıyla ilgili olduğu ortaya konmuştur. Kısacası, biçimsel öğeleri de işler hale getirip bazı yapısal öğelerin doğru bir şekilde kullanılmadığı görülmektedir.

\section{Yapısal Hatalar}

Yapısal kategoride en sık yapılan hatalar aşağıdaki tabloda verilmiştir: 
Tablo 2. Çevirilerdeki Yapısal Hatalar

\begin{tabular}{|c|c|c|}
\hline Alt kategori & Öğeler & Frekans \\
\hline \multirow{14}{*}{ Dilbilgisi } & Özne-yüklem uyumsuzluğu & 25 \\
\hline & İlgi tümceciği/adılı & 24 \\
\hline & Tamamlanmayan cümleler & 17 \\
\hline & Edatlar & 16 \\
\hline & Çoğul/tekil isimler & 14 \\
\hline & Zarflar & 11 \\
\hline & Etken/edilgen çatı & 10 \\
\hline & Belirli belirtme edat 1 & 8 \\
\hline & Belgisiz belirtme edatı & 7 \\
\hline & Bağlaçlar & 6 \\
\hline & Adillar & 5 \\
\hline & Fiilin çekimleri & 5 \\
\hline & Mastarlar & 4 \\
\hline & Karşılaştırma sıfatları & 3 \\
\hline \multirow{6}{*}{ Biçim } & Kelimenin yazımı & 19 \\
\hline & Virgül & 18 \\
\hline & Noktalı virgül & 2 \\
\hline & Tirnak işareti & 2 \\
\hline & Büyük harfle yazma & 2 \\
\hline & Sayıları yazma & 2 \\
\hline
\end{tabular}

En sık tekrarlanan hata, özne-yüklem uyumsuzluğudur (25). Bazı katılımcılar, tekillik ve çoğulluğa bakmaksızın özne ve yüklemi birbirine bağlarken hatalı cümleler kurmuştur. Katılımcıların hedef metinlerinden özne-yüklem uyumsuzluğunu içeren bazı alıntılar aşağıda verilmiştir:

"There are some communicational features that determine_every text according to position..."

“...some problems about issues that is related with your group of friends..."

"Running which is done at tracks that is appropriate to..."

Yukarıda görüldüğü gibi, yan cümlelerdeki özne ve yüklemler tekillik/çoğulluk bakımından uyumsuzdur.

Özne-yüklem uyumsuzluğu hatalarını, ilgi tümceciğinin/adılın eksik ya da yanlış kullanımından kaynaklanan hatalar (24) izlemektedir. Yanlış yapılandırılmış ilgi tümceciklerini gösteren bazı örnekler aşağıdadır:

"The movie which Watson plays..."

"There are situations that one word or clause gets a whole..."

"The movie that Jake meets with audience..." 
Ayrıca, yüklemi ya da öznesi olmadığı için tamamlanmamış cümleler (17) de en sık görülen üçüncü tür hatadır. $\mathrm{Bu}$ yüzden, bu cümleler kendi kendilerine bir anlam ifade edememektedir.

"In every text, due to the social setting in which it is formed, there are a couple of communicative features that specify." (eksik nesne)

"It does not mean that underestimation of importance of clauses or words.” (yan cümle tamamlanmamış)

"Beauty and the Beast compiled by the French writer in the $18^{\text {th }}$ century and giving inspiration to several works.” (eksik yüklem)

Doğru bir cümle oluşturabilmek için, özne, yüklem ve nesnelerin doğru bir şekilde yerleştirilmesi gerekmektedir. Yukarıdaki cümlelerde, ana öğeler (nesne ve yüklem) eksiktir, bu da onların tamamlanmamış cümleler olduğunu göstermektedir.

Biçim alt kategorisinde, atılmış ya da karıştırılmış harflerden dolayı kelimelerin yanlış yazımı (19) en sık yapılan hata olarak görülmektedir. Bazı örnekler:

"insignifant" for insignificant

"station" for situation

“COLLIDE" for COLLIDE"

"though" for "through"

"beatiful" for "beautiful"

İkinci olarak, virgül kullanımı $(\mathrm{N}=18)$ bazı katılımcıların problem yaşadığını göstermektedir; çünkü, virgül gereksiz yere kullanılmıştır. Bazı metinlerde, virgül, özneden sonra eklenerek yanlış kullanılmıştır.

"Thus, circumstances where a single word or sentence gain a whole text function, do not exist."

"Besides that, a successful translation, can occur with the close acknowledgement of some communicational features..."

Türkçe'de uzun cümlelerde virgül genellikle özneden sonra özneyi vurgulamak için konur; böylece, herhangi bir anlam karmaşası önlenmiş olur. (Türk Dil Kurumu [TDK], b.t). Bazı katılımcıların, anadillerindeki bu noktalama kuralını, hedef dile transfer ettiği görülmektedir. Diğer noktalama hataları ise, noktalı virgül (2) ve tırnak işareti (2) kullanımındadır. Son olarak, tabloda görüldüğü gibi, büyük harfle yazma (2) ve sayıların yazımı (2) ile ilgili hatalar çok nadir gözlemlenmiştir.

\section{Sözcüksel Hatalar}

Tablo 1'e dönecek olursak, uygun olmayan kelime kullanımının (69), ikinci en sık karşılaşılan hata olduğu görülebilir. Görüldüğü üzere, bazı ifadeler, gereğinden fazla uzundur ve net değildir, bu da orijinal anlamın ifade edilmesini engellemektedir. Bazı örnekler aşağıda verilmiştir:

"It does not mean that it reduces the importance of words and sentences. " (gereğinden fazla uzun ifade)

"...some conversational features that detects the text due to the communicational state in which it takes shape.” (net olmayan ifade)

“... a proper translation can take shape through close recognition of some communicational properties..." (yanlış kelime seçimi)

\section{Çevirisel/Yorumsal Hatalar}

Yapısal ve sözcüksel hataların yanı sıra, çevirisel/yorumsal hata kategorisinde, kaynak metindeki anlamı ifade edememe (37), yani, metin içindeki bilgiyi, fikri ya da herhangi bir kelimeyi çıkarma durumu gözlemlenmiştir. Bazı katılımcılar, kendilerine zor gelen kelime ya da ifadeyi çevirmekten kaçınmıştır; fakat bu çıkarma işlemi, çevirinin doğru anlamı ifade etmesine engel olmuş ve anlamı değiştirmiş̧tir. Ayrıca, diğer katılımcılar da aşağıdaki örneklerde verilen cümlelerdeki gibi orijinal metinde var olmayan kelimeleri ve fikirleri eklemişlerdir. 
“...considering so many relations of the text beyond the visible objective boundaries is the main condition of a good translation.” (Orijinal metinde bu durumdan ana koşul olarak değil, ön koşul olarak bahsedilmiştir; çevirisel/yorumsal hata)

"In fact, a single word or sentence can be functioned as a whole text." (Fakat, orijinal metinde şu şekilde ifade edilmektedir: "tek bir kelime ya da cümlenin tüm metin olarak işlev gördüğü bazı durumlar vardır."

“...it is extremely important to know both source and target language...” (Orijinal metinde konunun ne kadar önemli olduğu söylenmemesine rağmen, aday öğretmen, konunun ne kadar önemli olduğundan bahsetmiştir.)

\section{Tartışma ve Sonuç}

Bulgulara göre, çeviri hataları 1) yapısal, 2) sözcüksel ve 3) çevirisel/yorumsal hatalar olmak üzere 3 kategoriye ayrılmaktadır. Dilbigisi ve biçimsel öğeleri de içeren yapısal hatalar en sık görülen hatalardır. Yani, metinlerin büyük çoğunluğunun hedef dilin yapısal örüntülerine uygun olmayan şekilde oluşturulduğu sonucuna varılabilir. Bu çalışma için dikkatli şekilde yürütülen incelemelere göre, bazı katılımcıların özne-yüklem uyumu, ilgi tümceciği/adılı ve cümle yapısını göz önünde bulundurarak cümle kurma konusunda zorluk yaşadığı aşikardır. Tüm bu yapısal hata formları göz önünde bulundurulduğunda, katılımcıların nispeten daha uzun cümlelerin kurulumunda sorun yaşadığı belirtilebilir. Kısa ve direkt cümlelerde, herhangi bir yan ya da ek cümleyi ana cümleye bağlamaya gerek duyulmadığından, genellikle ilgi tümceciği ya da adılı bulunmaz. Özne ve yüklem arasındaki mesafe genellikle kısadır, böylece birbirinden çok fazla ayrılmazlar. Fakat, uzun cümlelerde diğer cümlelere bağlanması gereken bağımlı cümleler olduğu için, ilgi tümcecikleri ya da özne-yüklem uyumsuzluğu konusunda zayıf oluşturulmuş cümlelerin ortaya çıkması daha muhtemeldir.

Biçimsel hatalarla ilgili olarak, atılmış ya da karıştırılmış harflerden dolayı yanlış yazılan kelimeler büyük çoğunluğu oluşturmaktadır. Kısacası, bazı katılımcılar, hatasız kelime yazımı hususunda hazır değildir. Bu bulgular, Al-zuoud ve Kabilan'ın (2013) İngilizce öğrencilerinin, yazım hatalarını araştırdıkları ve hataların çoğunun 'yer değiştirme' ve 'çıkarma' hatalarından oluştuğunu belirttiği çalışmayla benzerdir. Benzer şekilde, Seitova’ nın (2016) Rus Kazak olan İngilizce öğrencilerinin dil hatalarını araştırdığı araştırmasında, esas hata kaynaklarından birinin yazım yanlışı olduğu ortaya çıkmıştır. Burada, bu çalışma bağlamında, katılımcıların muhtemelen yazım kontrolü yapmadığı sonucuna varılabilir. Bundan dolayı, bu biçimsel başarısızlık, sözcüksel gösterimdeki hata ile birlikte ele alınabilir.

Yazım yanlışlarının yanı sıra, başta virgül kullanımı olmak üzere, noktalama hususu da bazı katılımcılar için problem arz etmektedir. Virgülün uzun cümlelerle sıkça yanlış kullanıldığı ve bazı katılımcıların virgülü özneden sonra yerleştirerek özneyi diğer cümle ögelerinden ayırt etmek için kullandığı gözlemlenmiştir. Bu karmaşık durum bir dereceye kadar anlaşılabilir; çünkü, Türkçe 'de virgül özneyi vurgulamak için kullanılır. Bu yüzden, katılımcılar kendilerini anadillerinden sıyıramamış göründüğünden negatif bir diller arası etkileşimden bahsedilebilir.

İkinci en sık karşılaşılan hata uygun olmayan sözcük kullanımını belirten sözcüksel kategoridir. Bazı katılımcılar, doğru kelimeyi bulmakta zorlanmış ve gereğinden fazla uzun ifadeler kullanmışlardır. Bu bulgular, yanlış kelime kullanımının yaygın bir çeviri hatası olarak gözlemlendiği önceki çalışmalarla da örtüşmektedir (Parvizi, Shafipour \& Mashayekh, 2016; Pojprasat, 2007). Yanlış kelime kullanımının düşük sözcüksel edinimin göstergesi olabileceğini de belirtmek gerekir. Cronbach (1942, aktaran Stahl \& Bravo, 2010), bir kelimeyi tanımlamanın, farklı anlamlarını bilmenin, uygun kullanımının farkında olmanın, tüm bağlamlarda ve kelimeyi etkin bir şekilde kullanımının gerekli olduğunu belirtir. Görüldüğü gibi, kelimenin sadece tanımını bilmek yeterli değildir; bir kelimeyi bilmek, farkı anlam ve kullanımlarını da bilmeyi gerektirir. Bu açıdan, kelimeleri sözlükte aramak, kulağa hoş geleni seçip, rastgele herhangi bir bağlamda kullanmak, kelime gelişimi için etkili bir yöntem değildir. Asıl konu, doğru kelimeyi seçip kullanarak gereksiz yere kullanılan kelimeleri ve net olmayan ifadeleri elemektir.

Uygun olmayan kelime seçimi ile, katılımcıların kaynak metinden hedef metine çeviri yaparken net olmayan ifadeleri kullanması da muhtemeldir. Bağlama uygun olan kelimeyi seçemeyen bazı katılımcıların, orijinal metinde olmayan bazı kelimeleri/ifadeleri çıkardıkları veya ekledikleri gözlemlenmiştir. Dimitriu’ya (2004) göre, kaynak 
metindeki bazı kelimeleri veya ifadeleri çıkarmak, metni kültürel, dilsel, ya da ideolojik olarak adapte etmek için kullanılan bir çeviri stratejisidir. Bu çalışma bağlamında, hedef topluma göre bir uyumsama yapılmasına gerek görülmediğinden, katılımcılar tarafindan yapılan çıkarma işlemi, çeviri stratejisi olarak ele alınmamışır. Uygun olmayan kelime ve ifadelerin kullanılması ile bazı fikirlerin eklenmesi ya da çıkarılması, bazı katılımcıların ya bat ya da çık yaklaşımında bulunduğu anlamına gelebilir çünkü bazı bölümlerin olmadığı bir ödevi teslim etmenin iyi bir etki bırakmayacağına inanılmaktadır.

\section{Pedagojik Çıkarımlar}

S1k görülen hataların frekanslarının incelenmesi ile birlikte, bu hataların basit bir dikkat dağınıklığı eserinin olmadığı sonucuna varılabilir. Belirli dilbilgisi yapılarında ve sözcüksel hususlarla ilgili dil kullanımında bir sorun olduğu gözlemlenmektedir. Sorunu daha da kötü hale getirmemek için, İngilizce öğretmeni adaylarına yazma günlügü tutmaları önerilebilir. İstedikleri herhangi bir konu ya da olay hakkında yazabilir, yazdıklarını düzenli olarak kendi kendilerine ya da arkadaşları ile gözden geçirebilirler. Bu, yapısal ya da sözcüksel sorun yaşamalarını engelleyecektir; çünkü, düzenli olarak yazı yazmak, kelime ve belirli yapıları kolay bir şekilde hatırlamalarını sağlayacaktır. Ancak, yazma becerisi, yorucu olarak görülmesinden dolayı ve yazma becerisinden hızlı bir şekilde sonuç alınamayacağına dair olan düşünceden ötürü bu beceri ihmal edilmektedir. Bu yüzden, eğitmenler, girdikleri derslerle ilintili olarak verdikleri ödevlerde yazma becerisine yoğunlaşabilirler ve öğrencilerin yazdıklarını şekil ve içerik bakımından inceleleyebilirler. Kısacası, konu herhangi bir yazılı ürün ortaya koymak değildir, amaç bilgili ve yetkin dil öğretmeni yetiştirmek olduğundan iyi yapılandırılmış bir ürün ortaya koymaktır.

Bunların yanı sıra, aday öğretmenleri Thesaurus kullanmaları konusunda teşvik etmek çevirileri daha iyi hale getirebilmek için küçük fakat etkili bir yöntem olabilir çünkü Thesaurus sözcükleri eş ve karşıt anlamlarıyla birlikte listelemektedir. Çevrimiçi Thesaurus web sayfaları, sözcükleri eş ve karşıı anlam ilişkisine ve anlamsal uygunluğa göre sıralandırmaktadır. Belirsizlik içinde olmak yerine, Thesaurus kullanımı, aday öğretmenlerin sözcüklerin kavramsal ilişkilerine dikkat ederek, doğru kelimeyi bulmasını sağlayabilir. Thesaurus'un yanı sıra, kaynak dilden kaynak dile tanımlamaların yapıldığı ve örneklerin verildiği tek dilli sözlükler de kullanılabilir. Çift dilli sözlükler bazı öğrenciler açısından yanlış yönlendirici olabilir; çünkü, bu sözlükler direkt olarak ana dildeki karşıllı̆̆nı vermektedir; ancak, verilen tanım hedef dildeki bağlama tamamen uymayabilir. Bu yüzden, tek dilli sözlükler, kelimelerin kullanıldığı bağlamları da verdiği için, nispeten daha etkilidir.

\section{References}

Al-Musawi, N. M. (2014). Strategic use of translation in learning English as a Foreign Language (EFL) among Bahrain University students. Innovative Teaching, 3. Retrieved from https://journals.sagepub.com/doi/pdf/10.2466/10.03.IT.3.4

Al-zuoud, K. M., \& Kabilan, K. M. (2013). Investigating Jordanian EFL students' spelling errors at tertiary level. International Journal of Linguistics, 5(3), 164-176.

Artar, P. (2017). The role of translation in foreign-language-teaching [Doctoral dissertation]. Universitat Rovira I Virgili, Tarragona, Spain.

Bowen, G. A. (2009). Document analysis as a qualitative research method. Qualitative Research Journal, 9(2), 27-40.

Çalış, E., \& Dikilitaş, K. (2012). The use of translation in EFL classes as L2 learning practice. Procedia- Social and Behavioral Sciences, 46, 5079-5084.

Council of Europe (2001). Common European Framework of Reference for Languages: Learning, teaching and assessment. Retrieved from https://rm.coe.int/1680459f97

Corder, P. (1967). The significance of learners' errors. International Review of Applied Linguistics, 5, 161-170. 
Dagiliene, I. (2012). Translation as a learning method in English language teaching. Studies about Languages, 21, 124-129.

Dimitriu, R. (2004). Omission in translation. Studies in Translation Theory and Practice, 12(3), 163-175.

Hervey, S., Loughridge, M., \& Higgings, I. (2006). Thinking German translation. NY: Routledge.

Kupske, F. F. (2015). Second language pedagogy and translation: The role of learners' own language and explicit instruction revisited. Brazilian English Language Teaching Journal, 6(1), 67-81.

Lee, T.Y. (2013). Incorporating translation into the language classroom and its potential impacts upon L2 learners. In D. Tsigari \& G. Floros (Eds.), Translation in language teaching and assessment (3-22). UK: Cambridge Scholars Publishing.

Leonardi, V. (2011). Pedagogical translation as a naturally-occuring cognitive and linguistic activity in foreign language learning. Annali Online di Lettere-Ferrara, 1-2 (17/28). Retrieved from http://annali.unife.it/lettere/article/viewFile/234/183

Luitel, B. (2017). Translation bridge as a facilitator in ESL reading comprehension. Empirical evidence. The Warwick ELT, 9. Retrieved from https://thewarwickeltezine.wordpress.com/2017/08/

Melis, N. M., \& Albir, A. H. (2001). Assessment in translation studies: Research needs. Meta, 46(2), $272-282$.

Mogahed, M. (2011). To use or not to use translation in language teaching. Translation Journal, 15(4). Retrieved from https://translationjournal.net/journal/58education.htm

Nord, C. (1997). Translating as a purposeful activity: Functionalist approaches explained. UK: St. Jerome Publishing.

Parvizi, G. R., Shafipour, M., \& Mashayekh, J. (2016). An examination of the errors committed by Iranian MA students in their translation of advertisement slogans based on Keshavarz's taxonomy of errors. Cross-Cultural Communication, 12(12), 1-13.

Pavan, E. (2013). The Simpsons: Translation and language teaching in an EFL class. Studies in Second Language Learning and Teaching, 3(1), 131-145.

Pojprasat, S. (2007). An analysis of translation errors made by Mattayomsuksa 6 students (Master's thesis). Srinakharinwirot University, Thailand.

Pouya, F. (2012). On the effect of translation on promoting reading comprehension in ESP. Journal of Basic and Applied Scientific Research, 2(7), 6495-6502.

Pym, A. (1992). Translation error analysis and the interface with language teaching. In C. Dollerup \& A. Loddegaard (Eds.), The teaching of translation (pp. 279-288). Retrieved from http://usuaris.tinet.cat/apym/online/training/1992_error.pdf

Richards, J. C. (1980). Second language acquisition: Error analysis. Annual Review of Applied Linguistics, 1, 91107.

Samardali, M. F. S. (2017). Translation as a tool for teaching English as a second language. Journal of Literature, Languages and Linguistics, 40, 64-69.

Seitova, M. (2016). Error analysis of written production. The case of 6th grade students of Kazakhstani School. Procedia-Social and Behavioral Sciences, 232, 287-293. 
Selinker, L. (1972). Interlanguage. International Review of Applied Linguistics, 10(3), 209-231.

Shoeib, A. (2016). The appropriateness of translation in EFL Learning: A case study of Albaha University learners' and teachers' perspectives, KSA. A ğrı İbrahim Çeçen Üniversitesi Sosyal Bilimler Enstitüsü Dergisi, 2(2), 80109.

Stahl, K. A. D., \& Bravo, M. A. (2010). Contemporary classroom vocabulary assessment for content areas. The Reading Teacher, 63(7), 566-578.

Translation (n.d). Retrieved from https://www.collinsdictionary.com/dictionary/english/translation

Turkish National Association [Türk Dil Kurumu] (n.d). Noktalama işaretleri [Punctuation marks]. Retrieved from http://www.tdk.gov.tr/index.php?option=com_content\&view=article\&id=187

Vivanco, H., Palazuelos, J. C., Garbarini, C., \& Blatrach, M. (1990). Error analysis in translation: A preliminary report. Meta, 35(3), 538-542.

Widdowson, H. G. (1978). Teaching language as communication. Oxford: Oxford University Press.

Witte, A. (2009). From translating to translation in foreign language learning. In A. Witte, T. Harden, \& Harden, A. R. O. (Eds.), Translation in second language learning and teaching (79-98). Bern: International Academic Publishers.

Yükseköğretim Kurulu [Council of Higher Education]. (2018). Ingilizce öğretmenliği lisans programı [Undergraduate program for English language teaching department]. Retrieved from http://www.yok.gov.tr/documents/10279/41805112/Ingilizce_Ogretmenligi_Lisans_Programi.pdf 